\title{
"There is no home for me in this world": States of statelessness and the need to deterritorialize human rights
}

\author{
Maria-Carolina Cambre \\ University of Alberta \\ carolina.cambre@ualberta.ca
}

\begin{abstract}
"Imprisoned by four walls
(to the North, ... a landscape to be invented: to the South, reflective memory

to the East, the mirror: to the West, stone and the song of silence)

I wrote messages, but received no reply.” Octavio Paz (Envoi)
\end{abstract}

"There is no there, there"

Gertrude Stein

\begin{abstract}
There are millions of people in the world today who 'reside' in no place. Technically, though, no place simply means a non-existent place, which by extension annuls the existence of these people. May of these are from areas where they not recognized as citizens, and from where they have been uprooted because of war and related upheavals. In these instances, these have no other choice but to seek other places to live. It is indeed, when the doors are shut and they are not accepted in the new places that they become denationalized and trapped in 'no-man's land.' Such acts of exclusion are dehumanizing, painful and should not be accepted in our world. In this paper, I argue that this widespread problem exists due to lack of basic citizenship and human rights possibilities. The problem is also attached to specific understandings of sovereignty and human rights where, in the case of a conflict, for example, whatever the nation-state almost always takes precedence over the fundamental rights of the individual and/or groups. Indeed, this problematic reality is discursively (as well as pragmatically) located within the human rights, and related governance debates, which always display some form of conceptual and practical disconnect between the nation-state's right to refuse entry, and an individual's right for asylum.
\end{abstract}

Cultural and Pedagogical Inquiry, 2010, 1(2), pp.45-66

ISSN 1916-3460 @ 2010 University of Alberta

http://ejournals.library.ualberta.ca/index.php/cpi/index 


\section{Introduction}

Millions of migrating people, invisibly imprisoned, can testify this non-place described by Octavio Paz, and Gertrude Stein's not-there, does exist. Many, as individuals as well as groups, come from places which no longer recognize them as citizens, or whose borders have changed through war. They have fled, are fleeing, hiding, or have been expelled. Those who can travel seek asylum, but many are refused: they are no longer "persons of concern", and are immobile without proper documents. Denationalized, they are trapped in various "no-man's lands" around the world. Their stories are diverse, from the strange to the heart breaking, ranging widely in complexity. However they all reveal a defenselessness and a frustrated struggle against the dehumanization accompanying their states of statelessness.

The problem, I contend, is the handcuffing of basic human rights to the idea of citizenship so that the condition of statelessness also renders people unable to have a "meaningful place" (Parekh, 2004, p. 1) from which to speak and act. This problem is coupled with specific understandings of sovereignty and human rights where, in the case of a conflict, the will of the nation-state almost always trumps the rights of the individual or minority group. Current renditions of the concepts of sovereignty and citizenship within the human rights, and governance discourses display a tension between the nation-states right to refuse entry, and an individual's right for asylum. So what is required for every member of the human race to be able feel "at home" and equally entitled to inhabit the earth? Simone Weil's words, though written in 1949, still resonate and are worth remembering:

The notion of obligations comes before that of rights, which is subordinate and relative to the former. A right is not effectual by itself, but only in relation to the obligation to which it corresponds, the effective exercise of a right springing not from the individual who possesses it, but from other men who consider themselves as being under an obligation towards him. Recognition of an obligation makes it effectual. An obligation which goes unrecognized by anybody loses none of the full force of its existence. A right which goes unrecognized by anybody is not worth very much. (2002 edition p.3)

Fifty-five years later, Seyla Benhabib echoes Weil in The Rights of Others where she uses language that reveals the inseparability of rights and obligations. Describing and defending the cosmopolitan perspective, she builds on a Kantian view to remark, "if the actions of one can affect the actions of another' then we have the obligation to regulate our actions under a common law of freedom which respects our equality as moral agents" (2004, p. 104, my emphasis). Is it possible for policy makers to enable the universal protection of human rights without threatening nation-state sovereignty?

It is not necessary, or possible, to recount every single person or group's story of statelessness. Still, stories help reveal differences and similarities among the circumstances and contexts around being stateless, and highlight their complexity. Like lenses, they provide perspectives from which to consider the current discourses on human rights, citizenship, and governance. I will orient this discussion by providing a few examples chosen to highlight the sheer diversity of cases affected by this problem. In this way, the 
underlying concerns of key actors can be clarified and elaborated, and possible policy models can be proposed.

\section{Stories of the stateless}

The following cases illustrate the irreducible diversity of social, political and historical contexts where one person, or a group, can become "rightless" through varying degrees of statelessness. I begin with Shahroukh Khan who was born in Kabul. By the time he had reached his $18^{\text {th }}$ birthday, his father had been murdered in a blood feud: US American bombs had destroyed his family home in Kandahar and had killed his mother and two younger brothers and sisters soon after. When the United Nations High Commissioner for Refugees (UNHCR) rejected his application for asylum, "he swallowed a handful of pills, and hoped to die" (Yaghmaian, 2003, p. 1). As an adolescent, he became an illegal refugee in Istanbul, and one of the "tens of thousands of migrants and asylum seekers, men and women who cross multiple borders, live in destitution, exist in the margins of inhospitable societies and dream of better days ahead" (Yaghmaian, 2003, p. 6). His story is a common one.

Other stories are stranger than fiction. In 1977, Merhan Karimi Nasseri was expelled from Iran without a passport for protesting against the shah of Iran, Mohammad Reza Pahlavi. Nasseri applied for refugee status in Europe and was repeatedly refused. Finally after four years, his request for political asylum from Iran was granted by the UNHCR in Belgium. Nasseri decided in 1986 to go to England in search of relatives. Unfortunately, his refugee documents were stolen in Paris, 1988. When found without a passport, British officials sent him back to Charles de Gaulle Airport. At first, the French police arrested him for illegal entry, but as Nasseri had no documents, there was no country to which he could be deported.

This complicated combination of bureaucratic mishaps and bad luck led to the now legendary story of Nasseri's wait of over fifteen years in Terminal One of Charles De Gaulle airport. In 1992, a French court ruled that Nasseri had entered the airport legally as a refugee and could not be expelled from it. The court could not force the French government to allow him out of the airport onto French soil, or to give Nasseri either a refugee or transit visa. Belgium did finally grant him refugee credentials in 1999, but by then the serious deterioration of his mental state, from so many years without setting foot outside the terminal, made him afraid to leave. "He used to be a normal person. By spending 15 years in that place, he has become institutionalized," says Mr. Kouros, (Gilsdorf, 2004, p. 1). The psychological price he has paid in his fight to become a man who belongs somewhere has been too high, "Nobody could suffer all he did and stay normal," noted his lawyer, Bourget (Neuffer, 1997, p. 2).

Nasseri inspired movies, including The Terminal, and had become an unlikely tourist attraction. To this day no one has claimed him as a relation, and only in 2006 was he hospitalized by the state. "Nasseri is convinced he has no official identity" (Gilsdorf, 2004, p. 1). Danielle Yzerman, spokeswoman for Charles de Gaulle airport, said, "An airport is kind of a place between heaven and earth...He has found a home here" (Neuffer, 1997, p. 4). But, an airport is no home. Other solutions must exist for those caught in bureaucratic noman's lands, or who are unwanted by any nation-state and unable to obtain refugee status. Both these cases demonstrate not only the needless suffering and vulnerability of individuals 
who find themselves without "papers", but also the inhumane face of officialdom. Such humiliations are visited on those outside the majority world also, as my next example demonstrates.

For thirteen years, a certain American citizen was wanted in the USA on criminal charges. After hovering below the radar for years, he was "kidnapped" in Japan and held in a detention center for 8 months. He is a hero to some and a laughing stock to others. Did he supply weapons to terrorists, raise money for arms or threaten to assassinate the President? No, the man who is often quoted as saying, "all I want to do, ever, is just play chess" has been found guilty of playing a game of chess in the former Yugoslavia and violating US sanctions. Luckily for Bobby Fischer, Iceland extended him a hand and granted him citizenship mainly because Icelanders cherished his status as the greatest chess champion in the world. What would have happened to Mr. Fischer otherwise? As Fischer himself observed, "It's like in the comics, like Billy Batson used to say 'Shazaaam!' and he becomes Captain Marvel. He (Bush) just says 'Enemy Combatant! Now you have no legal rights" (AP interview, Mar. 28, 2005).

Bobby Fischer became an international star in 1972 when he defeated the Russian champion, Boris Spassky, but when he played an exhibition game against Spassky in 1992 in Yugoslavia, from which American citizens were barred, he became a fugitive. However, because of his fame, he still receives attention from the media and can say things such as:

The United States is an illegitimate country ... "That country, the United States, belongs to the red man, the American Indian. ... It's actually a shame to be a so-called American because everybody living there is ... an invader. (AP interview, Mar. 28, 2005)

Others are not so privileged.

Jeremy Hinzman, a soldier in the 82nd Airborne Division for example, sought refugee status in Canada as an objector to the US government's war on Iraq. Brandon Hughey, a 19-year-old American soldier, followed two months later also seeking refugee status. Canada refuses to allow them to stay, although Canadians are still rallying on their behalf. Hughey notes:

They ... tell me that I have no choice but to pack my bags and get ready to go to Iraq. This has led me to feel hopeless and I have thought about suicide several times. (Soloman, 2004, p. N.A.)

According to Soloman's (2004) report, many share the desperation that led these soldiers to desert. The suicide rate among service members is at an all-time high.

From April through December last year, 23 killed themselves while on duty in Iraq or Kuwait; at least seven more did so after their return home... Calls to G.I. Rights Hotline, which answers questions from recruits trying to leave the armed forces, shot up to 28,822 in 2003, from 17,267 in 2001. Meanwhile, though the Pentagon will not confirm figures, military attorneys, activists, and the European press have estimated that 600 to 1,700 soldiers have fled to avoid service in Iraq. (p. N.A.) 
Possibly, hundreds of servicemen and women are living underground in the US. Yet, they can still be considered "lucky" in comparison to others. The Fischer and Hinzman cases reveal that citizens of rich and powerful nations can suddenly be in a position where they have lost their rights.

This kind of vulnerability is not restricted to individuals alone. Hundreds of Burmese activists working for democracy, and human rights, are unsafe in their own country and have applied to Thailand for asylum. However, they no longer feel safe there because the Thai government has decided to relocate those who have POC (Person of Concern) status from the UNHCR to refugee camps on the Burmese border where there is possibility of attack. There is nothing they can do, according to the Indymedia on-line report; "Thailand is not a signatory to the UN Convention on the Status of Refugees, which makes UNHCR and international refugee law powerless. There is also no basic legal framework through which asylum claims can be made" (N/A 27 Mar 2005). What happens to those people who did not gain even refugee status? Do they simply disappear?

Other groups, while still residing in their countries, face a similar "rightless" status making them defenseless. Lack of border crossing rights for communities straddling boundary-lines, such as the Tohono O'odham on the Mexican-US border, denies their fundamental human rights and threatens continued existence of their culture (see LunaFirebaugh in "The border crossed us"). Even those who legitimately traverse borders as part of their way of life, like the Roma in Europe, are criminalized. According to Union Chief Emil Scuka, the Roma hope to establish new statutes in an International Romany Union to, "... highlight that we are a nation, in Europe and in the world," (Global Policy Forum, 2000, Para. 2) as a shield from ongoing discrimination. Max van der Stoel, the Organization for Security and Cooperation in Europe's High Commissioner on National Minorities (OSCE) warned that gypsies face what amount to "pogroms" in some countries saying, "Front and centre among those persons being left outside Europe's new security and prosperity are the Roma" (Global Policy Forum, 2000, Para. 5). Clearly the abstract rights provided in a liberal tradition of citizenship do not mitigate the inequalities related to ethnicity, class, disability and gender. For instance, O'Connell, (1996) observes that while Irish Travelers are citizens in name, they are denied many of the rights one normally associates with citizenship. Members of these trans-territorial groups may have official legitimacy with respect to their citizen status, but they are still treated in a manner penalizing them for their way of life. Travelers, Gypsies, Indigenous tribes and other minority ethnic groups are treated as secondclass citizens. "Citizenship therefore can become a site for struggle to meet basic needs and achieve human rights and equality" (Benhabib, 2005, p. 2).

A similar lack of social integration and economic mobility plagues Turkish Gastarbeiter (guestworker) communities. Arguing for the admission of Turkey into the EU, Seyla Benhabib (2005) writes, "Germany is home to roughly 1.9 million Turkish workers; the Netherlands to a little under a million, and France to about half a million. Altogether, there are close to 3.5 million Turkish nationals living in EU states" (p. 3). Though they have Turkish citizenship, they must inhabit other European countries in order to work. Like many other migrant worker groups, they are without rights regardless of how long they have been in the host country, although they are needed and authorized. The oxymoronic term "guestworker" is oddly appropriate since it is contradictory to have both roles simultaneously so that virtually they are trapped in a no-place already. These communities find themselves in the inhospitable gap between "guest" and "worker" where they are 
considered "workers" only while working, "guests" when they are not, and basically unwelcome all the time.

Besides migrant groups residing outside their nation of origin and nomadic groups without official nations of origin, there are many internally displaced groups. The 1991 decree on the "Restoration of Latvian Citizenry and Basic Principles of Naturalization," states that people who settled in Latvia after 1940 and their descendants are illegal immigrants. Accordingly, citizenship is awarded only if one can prove a consanguineous relation to persons of the first Latvian republic. This policy immediately creates 700,000 stateless persons out of 2.56 million (Vebers, 1994, p.3 in Rosengaard, 1996, p. 4). In Lost Russians of Latvia, Rosengaard (1996) states:

The vast majority of non-citizens are ethnic Russians or Russian- speaking Slavs. Being a non-citizen entails not only a total lack of political rights; social and economical rights are also affected; "over 60 laws, decrees and other normative acts have been imposed upon non-citizens resulting in an array of restrictions of the social, economic, property and employment rights" (Tsilevich 1995, p. 47). As a result of these restrictions, the Russians have been transformed from an ethnic minority into a socially disadvantaged group. (Rosengaard, 1996, p. 4)

In the process of cutting this group loose from any roots or official ties to the land, the Latvian government is rewriting history. A shared history where immigrant Russians once had a significant role has not only been suppressed, but also erased. As one WWII veteran recalls:

My friends and I gave our blood for the liberation of Latvia during the war, we were met with flowers by the Latvian people every time we liberated another Latvian town. Today they call us occupants. (Rosengaard, 1996, p. 5)

The message is clear; not only are you not, but also you never were. Without moving, or crossing any borders, these Russians find themselves denationalized; "Rather than being a foreign country ... the past is a lost country." (Rosengaard, 1996, p. 5)

Khan, Nasseri, Fischer, and the American war resisters have unique individual stories. The Burmese human rights workers have very different situations from the Roma, the Tohono O'odham, the Turkish "guestworkers", and the Russians in Latvia. Nevertheless, they can all say they are out of place, and "home" is not equal to the place they inhabit. Home is a dream for some, a memory for others, and, for most, something they cannot have. In this way, they have joined thousands of others who inhabit the no-places. There are over 10 million refugees around the world, as well as many millions of others who have been forcibly displaced as a result of conflict, war, religious or political discrimination and ethnic cleansing. Thousands of migrant workers are unaccounted for, millions of child laborers are out of the reach of "statistical observation", diverse "undesirable" groups, are bypassed, and left to themselves, undocumented. Without documents, they are also without social, political and civil rights, not to mention those rights declared "inalienable" by the UN.

Whether intentionally or not, these people have been deterritorialized as a result of their transgression of obligatory lines of communication, or changes in rules of government, 
or an exclusionary structure of power. Originally coined by Gilles Deleuze and Félix Guattari in Anti-Oedipus (1972), deterritorialization is a term transformed and appropriated across disciplines. This term, as rendered by Kenneth Skinner (2005), whom I draw on here, expresses detachment of social forms from geography. However he is aware of the potential scope of the word when he states that some researchers have seen "deterritorialization as the centerpiece of globalization" (Skinner, 2005, p.1), while others have seen it as purely philosophical.

\section{Deterritorialization}

To understand which groups and individuals can be described as "stateless" and consequently "rightless", an understanding of the concept of deterritorialization is both helpful and necessary. Granted, even the most detailed descriptions of different degrees and manifestations of deterritorialization will not be comprehensive. As these stories show, every context is unique and sometimes events can present unexpected, even inexplicable, circumstances for people. However, this is not a warrant to be vague, it is a reminder that concepts are fluid by necessity, and that the elaboration of an idea represents a moment of traction instead of the static grounding of a framework. As metaphors, frameworks organize experience and guide actions, functioning as symbolic representations and cognitive keys that model behaviour and help people to assess events. In itself, the metaphor of a framework seems to be omnipresent across policy discourses. Though it provides a practical conceptual structure that can be filled and fleshed out, in the context of the globalization of interconnected sub and supra governmental forms, and non-governmental agencies and bodies, it becomes problematic. For a metaphor to be appropriate it must, at the very least, not be out of tune with current realities.

R.A.W. Rhodes (1996) describes policy outcomes as the product of interactions between local government, regional authorities, the voluntary sector and the private sector, rather than the result of a central government's actions. He observes "there is order in the policy area but it is not imposed from on high: it emerges from the negotiations of the several affected parties" (p. 657). While examining patterns of interaction such as self and co-regulation, public-private partnerships, co-operative management, and joint entrepreneurial ventures both within and between states, Rhodes (1996) argues that many and varied arrangements are necessary because, "we live in the centerless society...in the polycentric state characterized by multiple centres" (p. 657). The multi-nodal webs of everchanging forms of social coordination function as networks. For Rhodes (1996), governance $i s$ managing networks, in the sense of steering not driving. Perhaps, the network form, as a metaphor, can be pressed into the service of policy discourses. It may be fruitful to engage this metaphor to work with the concept of deterritorialization. A hierarchical bureaucratic framework is to rhizomatic networks what government is to governance.

Having said this, it is worth keeping in mind that network forms develop at different speeds and in different ways depending on context. These uneven gap-filled processes are exemplified by the highly centralized financial sector, where the state's power is entrenched although it must negotiate with transnational corporations. Thus, seemingly autonomous nodes of the network can still be controlled to some extent by the state, and the network has not completely replaced the "framework" of the bureaucratic hierarchy. 
In Skinner's (2005) discussion of Guattari's (1991) focus on territorial analysis, he wonders if the nature of attachment between social forms and geography has fluctuated over time. Correspondingly, Mazrui (2004) notes, "The history of human kind is, on the whole, a history of changing boundaries and expanding societal scale" (p. 5). A territory is not necessarily a geographical landform; it can be grasped psychologically as a person's habits or social environment. It can also be recognized behaviourally as the patterns of interactions between members of a group such as a wolf pack. Either way "territory" implies a form of location with some degree of stability so that a person can have a relationship with it. Territory as property rights in the Western paradigm differs from most Indigenous peoples' views. A territory can also be an area of knowledge, investigation or experience. Even consumer taste is a territory, "programmed to suit the commodities of one production-cycle, then de-programmed and re-programmed for the next" (Skinner, 2005, p. 11).

Territorializations, as well as deterritorializations, are processes understood in very differently by theorists. Lacan would describe the impression of the mother's care on the child's libido as a psychological territorialization, while Deleuze and Guattari see deterritorialization as the liberation of the libido from its objects of investment, psychologically. Socially, they also see it as a liberation of labour power from a means of production such as land. Therefore, "peasants are deterritorialized from the land only to be reterritorialized onto textile looms" (Skinner, 2005, p. 9). If the only world market is the capitalist one, as Deleuze and Guattari believe, then alternatives can be imagined, philosophically, as deterritorializations, or even the extra-territorial as in the case of hopes and dreams.

For example, students involved in the Paris uprisings of 1968 had the slogan, "let us be realistic and demand the impossible". Today in the province of Neuquen in Argentina, graffiti art proclaims, "Our dreams don't fit on your ballots". Finally, there is the statement by the three-year-old Alphonsine, "I'm not human. I'm an Indian" (Findlay, 2000, p. 307). These statements take deterritorialization and expand it into a space of non-representability. They use these expressions politically to underline the conflict or chasm between their needs and desires on one hand, and the limiting offerings of the state on the other. Productively, philosophical imaginings can contribute "to the intensification of the perception of the present moment as they amplify formal investigation itself" (Süssekind. 2002, p. 19). These kinds of statements also demonstrate that people are capable of imagining otherwise.

Thus, the concept "deterritorialization" can be fruitfully employed in a variety of ways. For my purposes, a person, or group, is "deterritorialized" in all of the following scenarios. The denationalization of a person or group for reasons of ethnicity, gender identification, or beliefs, whether they be political or religious, even if they have engaged in criminal activity makes them "deterritorialized" whether they have had to leave their land of origin or not. So both those who identify themselves as refugees, or as internally displaced persons are deterritorialized as in the cases of Nasseri and the American soldiers who are AWOL. In addition, migrant-workers, sex-slaves, or those who have citizenship in one nation-state but need to, or are forced to, work and live (even seasonally) in another nationstate because of economic necessity are deterritorialized. Indigenous groups, or those whose identity and traditional way of life is necessarily transnational or international, such as the Roma, are included as deterritorialized. Anyone taken to a "non-place" like Guantánamo Bay is deterritorialized. Finally, immigrants who choose to maintain their previous 
citizenship in nations who do not grant dual citizenship (such as the USA), and are thus unrecognized as full citizens where they reside are deterritorialized.

Naturally, those living in nations where they enjoy full civic, social, economic, and human rights are not deterritorialized. On the other hand, someone who has not qualified for immigration, a temporary or other visa, but enters, (by smuggling or other means), into a state regardless, is not automatically deterritorialized. There does not seem to be a common measure by which to compare and judge varying cases of deterritorialization, as the sample cases show. Adding to the confusion, sometimes language use may mask deterritorialization as in the case of the deceptive expression "local participation" in Nepal, which has come to be synonymous with unpaid labour (Campbell, 2000, p. 9). However, a working definition of deterritorialized persons would generally include all those who have had their citizenship compromised to some degree for political, socio-economic, or ethnic or religious reasons in such a way as to lose the "right to have rights" (Arendt in Parekh 2004).

Perhaps the concept of citizenship can also be deterritorialized simply by having it, as a package of rights, detached from the nation-state as the only granting authority. By its very nature, citizenship consists of exclusions, if some kind of citizenship is required in order for one to be recognized as a human being with fundamental rights, then alternative citizenships create possibilities for amplifying the very concept. It is worth wondering what kind of world would emerge.

\section{Human rights and alternative citizenships}

"The ever-present theme of colonization of the writer that aspires to be citizen of the world and ends up Manhattanizing her reality to make it more universal without discovering that in the process, the only thing accomplished is a negation of her own identity." (Ilich, 2004, p.1 Author's translation). ${ }^{1}$

The literature on contemporary citizenships is emerging as a way to rethink the traditional coupling of citizenship and the nation-state by exploring alternative sets of principles, forms and practices of citizenship (See for example, Baubock, 1994; Axtman, 1996; Isin and Wood, 1999; Ong, 1999; Yuval-Davis, 1999, Purcell, 2003). Around the world, activists, intellectuals and government officials, indigenous groups and others are experimenting with various definitions of citizenship, revealing the great need for new conceptualizations.

Questions pertaining to deterritorialized persons or groups would also inquire into citizenship. How far can citizenship stretch? What protection do individuals or groups have if nations revoke their citizenship? The rights discourse is directly linked to the current citizenship debate, as well as being inextricably entangled with indigenous peoples' struggles. "Indeed the whole concept of indigenous peoples is now inseparable from human rights discourses which represent them as victims of abusive governments" (Cameron, 2000, p. 8). Further, Cast ells (1998) claims, "If a phenomenon is acknowledged as a fundamental dimension of our societies, indeed of the new, globalized system, we must explore...[it]" (p.

\footnotetext{
1 “el siempre presente tema de la colonización del escritor que aspira a ser ciudadano del mundo y termina manhattanizando su realidad para hacerla mas universal sin enterarse que en el proceso lo único que logra es negar su propia identidad."
} 
173). Though exploring all these intersecting and overlapping discussions on citizenship and human rights is necessary, it is beyond this paper's immediate scope. However, some key themes with respect to deterritorializing citizenship emerge through Mark Purcell's (2003) innovative work in Citizenship and the right to the global city: re-imagining the capitalist world order. Purcell provides a springboard for thoughts on how citizenship can be re-figured and perhaps provide truly "inalienable" rights.

Generally, the predominant concept of citizenship in Western literature is the liberaldemocratic notion that "individual political actors agree to a 'social contract' with the state in which they consent to be ruled in exchange for certain privileges and protections (Rousseau, 1987; Locke, 1988; Kant, 1991; Rawls, 1971; 1993)” (Purcell, p. 565). Purcell saw himself as part of a growing body of work (e.g. Staeheli, 1994; Trend, 1995; Brown, 1997; Benhabib, 1999; Soysal, 1999; Yuval-Davis, 1999) stretching the limits of this definition by exploring "group rather than individual identity, and membership in multiple communities outside the state, ones based on geography, ethnicity, sexuality, gender, the environment and so on" (p. 566).

He provides a detailed outline of global changes as the background for the contestation of traditional understandings of citizenship utilizing Marxist rather than Weberian views of the state. In this way, Purcell (2003) aligns himself with Henri Lefebvre's Marxist stance enabling him to make use of Lefebvre's concept of inhabitance as the foundation of political membership and the logic of material production (p. 565). Purcell can then argue "inhabitance, not nationality, forms the basis for political community and decision-making authority" (p. 566).

In the world described by Janusz Symonides (UNESCO Division of Human Rights report 1998) as increasingly interdependent in the economic, environmental and political spheres of all states, there has been a "hollowing out of the state" (Rhodes, 1996, p. 661). This global process "has resulted in a dilution of the traditional notion of state sovereignty. State sovereignty is also being eroded by growing free market economies and the increasingly important role played by some 18,000 to 20,000 non-governmental organisations (NGOs) world wide" (Symonides, 1998, p. n/a). Some state functions have also been shifted to both supranational (e.g. UN, NAFTA, ASEAN, WTO) and sub-national scales (Kearns, 1995; Swyngedouw, 1996; Staeheli et al., 1997; Ward, 2000; Purcell, 2003).

In this context of the destabilizing influence of global political-economic restructuring, reformulating citizenship, in turn, becomes urgent as a possible avenue for resisting capitalist social relations, "because someone will always be outside, excluded or below" (Purcell, p. 571) Presently, citizenship is a hierarchical and nested structure in which national-scale citizenship is the dominant form, one who is a citizen of Edmonton must first be a citizen of Alberta and prior to that, Canada for example.

Purcell focuses on three aspects to citizenship change; first, rescaling similar to that of capital accumulation and nation-state; second reterritorialization, so that many new forms don't assume as given either an association with national-scale territory, or the sovereignty of national-state citizenship; and third, reorientation, where a nation is no longer the primary community defining political identity and political loyalty. Many researchers are following similar paths: 
Besides the EU, other forms of supra-national and transnational citizenship are emerging, for example the environmental citizenship across the US-Mexico border (Pulido, 1994). Others have discussed 'cosmopolitan citizenship' and explored the possibility of global democracy (Gould, 1988; Held, 1995; Dauenhauer, 1996; Archibugi et al., 1998; Linklater, 1998; Hutchings and Dannreuther, 1999). All argue for a type of citizenship based on the universality of human existence instead of membership of a particular nation. Others argue nation-state is increasingly less relevant as the basis for citizenship especially in light of the growing transnational notions of rights and responsibilities. (Bhabha, 1999; Deflem and Pampel, 1996; Jacobson, 1996; King, 2000; Morris, 1997; Soysal, 1994; 1996; 1999) (Purcell, 2003, p. 572)

In addition, many have concentrated on the growing numbers of transnational migrants, people who do not permanently settle in a single nation-state (See for example: Baubock, 1994; Rouse, 1995; Schiller et al., 1995; Laguerre, 1998; Mitchell, 1998; Ong, 1999; Roberts et al., 1999; Mahler, 2000). Thus a "multi-layered citizen" is possible whose membership can have multiple referents based on one or more identities such as nation, ethnicity, gender, and sexuality (Sandel, 1996; Fincher, 1997; Yuval-Davis, 1999; Purcell, 2003).

The solution for Purcell (2003) is a combination of the reorientation-pluralization of citizenships as well as the politics of difference (i.e. members of community cannot be reduced to what they have in common), "rather, political identity, citizenship, and loyalty can and should embrace social difference among the members of a social community" (p. 575). The right to the global city becomes " a guiding principle for re-imagining the global political order" (p. 576) as well as challenging current notions of national sovereignty.

Exactly what a global city might be is not perfectly clear in Purcell's work. He seems to be describing those cities that have already emerged as international hubs for trade, tourism, and even educational meetings; cities such as Tokyo, Paris, London, New York, Mexico City et cetera. These "global cities do not nest neatly in a national-scale network of cities, and so ideas of citizenship attached in some way to the global city undermine the principle of urban citizenship nested in a sovereign nation-state"(Purcell, 2003, p. 573). They also contain large concentrations of transnational migrants.

"The right to the city imagines inhabitants to have two main rights: (1) the right to appropriate urban space [full and complete usage]; and (2) the right to participate centrally in the production of urban space (Lefebvre, 1968; 1996, p. 179)" (Purcell, 2003, p. 577). Hence, through inhabiting Los Angeles, you can be an "Angeleno inhabitant" and simultaneously a formal citizen of Mexico, a citadin-inhabitant of Los Angeles, and not a formal citizen of the United States. For Lefebvre, the right of appropriation is a right of use manifested through the right to participation: dynamic and performative.

Purcell's ideas do not actually represent the national outsourcing of the function of granting citizenship to the municipalities, however, in allowing someone who is citizen of Toronto, but not of Canada, to move in and out of the nation implies a sharing of power and responsibility. Which cities will qualify as "global" and who will decide? Municipal immigration policies would have to be developed. In terms of deterritorialized persons, there are some immediate advantages possible with Purcell's proposal. For instance, the reunification of families might be facilitated. The time spent waiting in limbo for a decision 
on status might be minimized. Perhaps exploitative and discriminatory treatment of migrant workers would be reduced. Granting citizenship, even a citadin-inhabitant one, to a large group could still be problematic socially and economically.

For many of the deterritorialized, the idea of multiplying the possibilities of acquiring citizenship through the right of inhabitance is a hopeful one, though it may not provide the solution for all who are stateless and rightless. At any rate, as a reterritorialization, the idea does not solve the problem of the immediate disintegration of one's "inalienable" rights the moment one is without citizenship status. It is important to remember that though relationships between states and individual citizens are changing in the era of globalization, the power of the state as an enforcer of individual rights and as a conduit to entitlements, political, economic or social, is still unrivalled.

... the effect of an individual's status on the ability to access rights vis-à-vis the state he or she lives in is critical. As statuses multiply, so the complexities in the relationship between state obligation and individual rights increase. ...Although they may all live permanently and feel they "belong" within the territory, citizens, illegal entrants, refugees, aliens dependants of citizens, nationals of associated states, and non-citizens with indefinite residence have radically different rights. (Bhabha J., 1999, p. 16)

The granting of rights is a sharing of power based on moral grounds so that individuals, or groups, have some minimal protection against being overwhelmed by economic and political forces. With respect to the question of power in current social relations and its relationship to rights, discussions of alternative citizenships seem to fall short. While Universalists see human rights in the liberal tradition, attained simply by being human, cultural relativists believe values are grounded in specific communities. In reality, as Joanne Bauer (2003) notes in The challenges to International human rights, "the ideological spectrum is much more complex; realizing that complexity can help point us to where the challenges to international human rights actually lie" (p. 2).

She invokes the Asian, African, Arab, and American national-regional perspectives as well as the opposing activist-intellectual views put forth mostly by NGO's in each region. In Africa, for instance, where primacy is placed on communal rights and the Western notion of the individual does not exist, the African charter illustrates specific historical socioeconomic concerns. Bauer writes, "In 1981, ... the Organization of African Unity adopted the African Charter for Human and Peoples' Rights, which emphasized economic, social, and cultural rights, the rights of people to self-determination, and the right to existence, equality, and nondomination" (p. 11). Bauer (2003) identifies an emerging international consensus in the principles underlying human rights discourses. Where different regions conflict is in the implementation and prioritization of rights. In terms of pursuing a way to ratify the "right to have rights" internationally, there is already a fertile ground and a favourable climate excepting, that is, in the USA. 


\section{United States and Exceptionalism}

US officials' use of legal reasoning to skirt the jurisdiction of international law when enemies are stateless and/or "terrorists" functions as a justification for the state's rights in a global war on terror. However, "the interpretative innovation of a category of "unlawful combatants' who have no legal rights has been challenged by international law experts" (Hajjar, 2005, p. 7). Bobby Fischer's Captain Marvel analogy is appropriate. US claims of absolute security as the legal right of the state annuls any of the rights of those perceived as threatening, and "Shazaaam" they are suddenly unlawful combatants.

In, From Nuremberg to Guantánamo: international law and American power politics, Lisa Hajjar (2005) calls this principle of absolute security as the state's right, "Israelization" (p.7). As a result of Israelization, anyone suspected of terrorist criminal activity, can be subjected to the rules of detention in war whether or not they have any connection with armed conflict. US officials justify evading their obligation under the very same rules to provide detainees with a hearing by using Guantánamo Bay. Geographically outside the United States, but rented from Cuba, Guantánamo Bay is not within a specific jurisdiction; it is literally nowhere in terms of the enforceability of laws. Thus, the United States uses its right of absolute security to deprive suspected "enemies" of their rights and make them legal nobodies. No governmental organization exists that can prevent "nobodies" from being taken "nowhere" and being tortured. What stops any authoritarian state from terminating its citizens' rights and creating other Guantánamos? The frightening answer is, nothing.

From the outset of the creation of international laws after World War II, the ability to enforce them was compromised. Most nations did not view human rights and humanitarian law as fully binding, and UN Security Council permanent members' veto power meant they could protect their individual interests regardless of international law. Although human rights protections have progressed with the institution of the UN tribunals and the World Court, it seems that whenever the United States is involved in gross violations directly or indirectly, they do not support the application of international law. This was "clearly evident in (their) refusal to turn over relevant documents to foreign governments, like Chile and Argentina, seeking to investigate and punish those responsible for gross violations in their "dirty wars" (Hijjar, p. 4). The US Senate has ratified few international laws:

...And, most notoriously, has not ratified the Convention on the Rights of the Child - the most widely and rapidly ratified human rights treaty in history, with 191 participating nations-making the United States the only country not to do so. Together with the efforts to reduce greenhouse gas emissions, the area in which American exceptionalism has most infuriated the international community has been in its refusal to support the International Criminal Court (Bauer, 2003, p. 9).

The importance of enabling international institutions to administer international laws cannot be overemphasized. The US practice of exceptionalism is an obstacle for the enforcement of human rights and humanitarian law in general. Behind the public discourses of sovereignty and security lie the more powerful discourses of fear: fear of losing social status and property, financial instability, internal dilemmas around race and ethnicity, fear of the criminal element and public safety. Perhaps the most ubiquitous fear, and the least 
discussed, is the fear nations represented as the "North" have of an inability to control the movements of populations of the "South".

\section{Global Governance}

Fran Ilich (2004) asks: "With which new hybrid narrative forms do we have to experiment to be able to generate dialogue and conversation with the public? How can these help convert the world into a better place to live? (p. 1, Author's translation)?",

It seems the democracy that had supposedly flourished throughout the $20^{\text {th }}$ century in so many countries did not pass beyond individual state borders. Even countries publicly upholding democratic practices and beliefs, behave as if the rest of the world were the lawless Wild West. A double standard can become visible with minimal exploration. In a world where democracies outnumber other types of government by far, does not every person at least have "the right to have rights"? For Rhodes (1996), governance refers directly to the steering of autonomous inter-organizational networks. He agrees with Rosenau in differentiating government as "activities that are backed by formal authority" from governance where "activities are backed by shared goals" (p. 657). Thus actors such as non-governmental organizations, the voluntary sector, and the private sector can participate in governance in their specific policy areas, through their own regulatory mechanisms without formal authority. Governance can function equally within or between states and organizations. Rhodes (1996) describes four shared characteristics of governance: (1) interdependence between organizations and shifting boundaries between the public, private, and voluntary sectors; (2) continuing exchange, sharing and negotiating between network members; (3) game-like interactions rooted in trust and regulated by rules; (4) a significant degree of autonomy from the state (p. 660). Democratic accountability can become a challenge if the state "becomes a collection of inter-organizational networks made up of governmental and societal actors with no sovereign actor able to steer or regulate" (p. 665). However, James Rosenau argues:

Given a world where governance is increasingly operative without government, where lines of authority are increasingly more informal than formal, where legitimacy is increasingly marked by ambiguity, citizens are increasingly capable of holding their own by knowing when, where, and how to engage in collective action (Rosenau in Rhodes, p. 667).

A much higher level of citizen engagement is necessary to preserve the public interest and "govern" networks of governance, however the state's role is significant if only to regulate accountability, which itself is becoming increasingly complex. However, on the world stage, the emergence of players other than nation-states (NGO's, voluntary and private sectors) creates the possibility of hope for deterritorialized persons.

2 “Con qué nuevas formas narrativas híbridas tenemos que experimentar para poder generar diálogo y conversación con el público? ¿Cómo pueden ayudar éstas a convertir el mundo en un mejor lugar para vivir?” (Illich, F. 2004, p. 1) 


\section{Policy claim}

The blind spot in current global governance policies exists where millions of people have been put in a position where they do not have the "right to have rights". Serena Parekh (2004), citing Arendt's description of Jews in Nazi Germany, writes,

They had 'lost the rights which had been thought of and even defined as inalienable, namely the Rights of Man ... . [they] had no governments to represent and to protect them' (Arendt 1971: 269). The problem, however, was not simply that their rights could no longer be protected, but that the very existence of rights was abolished in their becoming stateless (p. 42).

Today, people exist inside and outside the borders of the nations where they "belong" who are rendered stateless, and consequently rightless to varying degrees. Bobby Fischer's case, where another nation literally throws him a lifeline, is rare. There is a need then for global policies protecting the "deterritorialized" not directly dependent on one nation-state or another, or any geographical territory for that matter. Besides human rights justifications there is a justification based on security. The possibilities of conflict between and within groups, or even individuals, are higher when they have little to lose. Nations can claim they are not responsible for people who have "forfeited" their rights, and refuse to protect them, or actually persecute them further. The United Nations can claim they are doing all they can and are financially stretched to the limit. International governmental bodies may claim a multitude of NGOs exist to help "deterritorialized" people. Protecting those who cannot protect themselves is an ethical imperative, which is not being attended to.

Historically, the UNHCR has avoided articulating the refugee problem as a human rights problem in order to appear "non-political" and humanitarian, which was a political decision itself to evade getting entangled in Cold War real politik. It was only in 1981 that the UNHCR Executive committee drew upon basic human right standards in formulating its protection conclusions.

The inherent difficulties in defining and assessing state compliance, not to mention effecting and enforcing it is immense. One of the barriers, racism, provides even more reason for an incremental model with informational instruments to encourage greater understanding between ethnic groups, this "education" is especially important for immigration officers and those at service delivery points.

Interestingly, the Human Rights Committee's interpretation of the International Covenant on Civil and Political Rights 1966 (ICCPR) comment 15, notes that while the Covenant does not recognize the right of aliens to enter or reside in the territory of a state, in certain circumstances "an alien may enjoy the protection of the Covenant even in relation to entry or residence, for example, when considerations of non-discrimination, prohibition of inhuman treatment and respect to family life arise" (Gorlick, 2000, p. 16). Directly opposing interpretations of officers of the United States, which has allowed them to turn back Haitian refugees before reaching US soil, the Committee states, "concerning the extraterritorial application of the rights under the ICCPR, the consistent interpretation of the 
Committee on this subject, that, in special circumstances, persons may fall under the subject matter jurisdiction of a state party even when outside that state territory" (Gorlick, 2000, p. 16). Since protections for deterritorialized people are already enshrined in UN Covenants, two things are clear. First, this problem of "rights for the rightless," or the vulnerability of stateless people, has been already identified at different times and perhaps with different language. Second, the politics around compliance are still an ongoing issue and must be addressed.

Non-compliance by the United States and others such as Australia, and Malaysia provide a powerful impetus for other nation-states to maintain a convenient silence and do nothing. Politically, the international community must repeatedly voice their condemnation of rogue states (and it seems Venezuela at least has taken up this challenge). In terms of action, the layering of statuses for citizens provides more that one avenue of protection. The "global city" idea may not be impractical in the light of the recent state-like responses of various American cities ratifying of the Kyoto accord, and reducing greenhouse gas emissions, independently of the United States' (national level) decisions.

According to the UNHCR 1999 report describing the crisis in the system of international refugee protection, refugees today are swiftly losing ground in terms of legal protection provided by many states. The UNHCR publication, The state of the world's refugees 1997 provides the following figures:

The UNHCR is now responsible for the welfare of some 22 million people around the world, around 13 million of whom are refugees in the conventional sense of the word: people who have left their own country to escape from persecution, armed conflict or violence. To this figure can be added a very large number of uprooted people who do not receive any form of international protection or assistance...(p. 6)

How many would "a very large number" be? If they are uprooted, where are they and why are the figures not more accurate? The ambiguity in the report signals the seriousness of the problem.

The High Commissioner for Refugees noted in her address to the 54th session of the Commission of Human Rights: "there is an impressive array of international, regional and national human rights standards and structures which must continue to evolve to ensure that gaps and weaknesses are identified" referring, no doubt, to those in international protection regimes for refugees. (Gorlick. 2000, p. 6). Once "deterritorialized" people become a target group, the process of identifying members of this group is highly complex and costly. How will they be protected and where? Where can "stateless" people go? A new model of intervention needs to be designed. The social costs, in terms of lives lost, is also gloomily vast if nothing is done.

\section{Suggesting a Policy Model}

Pillow (1997) contends that traditional forms of policy development and analysis participate in a process of silencing. Policy archeology (Scheurich, 1994), though nebulous, has potential because it focuses on the regularities determining which policy problems and solutions are made visible and which remain invisible. Four arenas need to be examined: 
the education/social problem arena, the social regularities arena, the policy solutions arena, and the policy studies arena.

As a post-positivist policy analysis model, policy archeology is suitable for the application of tools such as focus groups, content analysis, and narrative policy analysis (though, there is a difference between analysis of narrative and narrative analysis). It is critical of the rational model and its emphasis on, and distinction between, facts and values. It is useful because it emphasizes the importance of conceptual frameworks, language, and the construction of reality.

With the vast number of players involved not only in terms of those who can be characterized as deterritorialized persons, but also regarding the number of nations, private and voluntary sectors, non-governmental and religious organizations whose input can contribute to the construction of public policy on a global scale, a philosophically coherent and pragmatically viable policy model for everyone is difficult to imagine.

Recognition of differences, and accommodations in global policy to demands grounded in those differences, calls for a constructivist stance and an incremental model where policy is made in small steps to cope with limited information, many players, and considers the rights and obligations of both individuals and groups. Taking into account that individual changes take place at the delivery points and so will vary substantially in the application of principles to meet the characteristics of each case (Pal, 2001), a global policy guiding local and national policies must have widespread support and legitimacy. Information-based policy instruments, insofar as these issues are connected to attitudinal factors such as racism would tap the power of information in promoting this discussion. A hybrid model combining elements of the political and democratic models would be a good start in the sense of providing space for many voices to be heard. The model would best be developed with the network form in mind, a deterritorialized model, so that a greater number of players would be incorporated in a horizontally rather than a vertically oriented relation.

\section{Conclusion}

Turkish singer/songwriter Sezen Aksu (2005) eloquently expresses a type of deterritorialization on her Bahane album. She sings, "Acinin yuzolcumu yeryuzunden cokmus aslinda" which means, "The surface area of pain is (actually) greater than the surface area of the earth". Problems surpassing distances and transgressing borders also go beyond existing conceptions of citizenship, and human rights as geographically bound. To respond appropriately, we must embrace philosophically deterritorialized ways of thinking with all their complexity and ambiguity. Once a person becomes "stateless" he or she de facto becomes "rightless", a deterritorialized person. How then, can other Holocausts be prevented? The protection of human rights must be divorced from the citizenship concept as it presently stands. This protection is not so much a "right" as it is an obligation in the sense intended by Simone Weil, but standing in the way of this is state self-interest manifested in forms such as exceptionalism.

Can we find a way to understand at least the right for human rights extraterritorially? Would it be too idealistic to think from a standpoint where the understanding of the individual would be in relation with human totality? A standpoint such as this would recognize our interconnectedness and mutual benefit in the existence and exercise of 
policies at a level both beyond and between nation-states. Perhaps a charter of nomadic rights can be developed, rights for those who cannot be assimilated, are ambiguously positioned, or doomed to wander. In An Anthropological Assessment of Globalization Defined as Deterritorialization, Skinner (2005), again following the philosophical developments initiated by Deleuze and Guattari, writes:

A nomadology would offer in place of the global free market and its axiomatic logic of deterritorializing singular diversities so that "all may speak" on a common planetary playing field, the extra-ideological democracy of singular diversity itself in the movement of an itinerant territoriality (p. 5) ...

As human beings we are bound to the earth and have some instinctive sense of "territoriality" be it virtual or concrete. But we have seen that this territoriality is not a fixed thing, nor is it something we can consensually define. At the same time, we have an awareness of our universalistic and boundless extra-territorial dimensions. These dimensions could be the key to finding a way to share the limited space on this planet because they offer experiences of communication that are successful without reducing the other to the same in the Foucaultian sense. Encountering the other as other is a profoundly ethical moment where we ourselves get displaced or deterritorialized because we experience communication as a rupture, a jarring recognition of the not-same and yet also human. This gap is the paradoxical building block for policy that understands the inseparability of rights and obligations as Benhabib has elaborated it. Nasseri was trapped in an airport for over a decade precisely because once his human rights evaporated with the disappearance of his papers, no policy existed to permit the recognition of an obligation towards him on the part of the city of Paris, or the state of France, or through any international body.

A nomadology would be a process involving the dynamic multidirectionality required to recognize an other. No point would be static, but each would still get traction while remaining mobile by retaining the complexity of both the multiple and the local. Philosophically, a nomadology would centre on finding meaning within the process itself in a way responsive to contingencies: as in ethics, the means is the ends. Simone Weil's words keep haunting us: we must reframe and shift our perspective to see that ultimately it is not about understanding the other as having rights, but of understanding ourselves as having obligations. The basic orientation of policy for those I have defined as deterritorialized must shift. The millions of people in refugee camps are like millions of Nasseri's trapped in a waiting zone without the "right to have rights". Developing principles on which to base international policy for nomadic rights is a start, but is not yet a ticket to fly.

\section{References}

Axtman, R. (1996) Liberal democracy into the twenty-first century:globalization, integration and the nation-state. Manchester University Press, Manchester. Baubock, R. (1994) Transnational citizenship: Membership rights in international migration. Edward Elgar, Brookfield, VT.

Bauer, S. (2003). "The challenges to international human rights" in Constructing 
Human Rights in the Age of Globalization, M. Monshipouri; N. Englehart; A. J. Nathan; K. Philip Eds. Armonk, N.Y.: M.E. Sharpe. Retrieved from http://www.cceia.org/resources/articles_papers_reports/905.html on March 30, 2005.

Benhabib, S. (1999) Citizens, residents, and aliens in a changing world: political membership in the global era. Social Research 66, 709-31

Benhabib, S. (2004). The rights of others: aliens, residents, and citizens. Cambridge: Cambridge University Press.

Benhabib, S. (2005). “Truly diverse?” In Global Agenda magazine. Retrieved Mar. 23, 2005 from http://www.globalagendamagazine.com/2005/seylabenhabib.asp.

Bhabha, J. (1999). Belonging in Europe: citizenship and post-national rights. UNESCO. Oxford: Blackwell Publishers.

Brown, M. (1997) Replacing citizenship: AIDS activism and radical democracy. Guilford Press, New York.

Cameron, G. (2000). "Taking Stock in Tanzania: Pastoralist NGOS and the Indigenous Question" paper presented at ROAPE Millennium Conference in Association with LUCAS (Draft of an Association of Social Anthropologists Conference Paper). $\begin{array}{llll}\text { Retrieved } \quad \text { March } & 2005 & \text { from }\end{array}$ http://www.asa2000.anthropology.ac.uk/cameron/cameron.html

Castells, M. (1998). The End of the Millennium, The Information Age: Economy, Society and Culture, Vol. III. Cambridge, MA; Oxford, UK: Blackwell.

Campbell, B. (2000, April 2-5). Whose knowledge? Indigenous views on the terms of development participation. Paper presented at the Association of Social Anthropologists Conference (ASA) called "Participating in development: Approaches to indigenous knowledge", University of London. Retrieved March 28, 2005 on from http://www.asa2000.anthropology.ac.uk/bcampbell/bcampbell.html

Fincher, R. (1997) Gender, age, and ethnicity in immigration for an Australian nation. Environment and Planning A 29, 217-36

Findlay, L. (2000) "Always Indigenize! The radical humanities in the postcolonial Canadian university”. ARIEL: A Review of International English Literature 31(1)\&(2), 307-

326

Isin E. and Wood P. (1999) Citizenship and identity. Sage, Thousand Oaks.

Luna-Firebaugh, E. M. (2002). The Border Crossed Us: Border Crossing Issues of the Indigenous Peoples of the Americas. Wicazo Sa Review, 17(1), Sovereignty and Governance, I (Spring), pp. 159-181 University of Minnesota Press.

Gilsdorf, E. (2004) "Behind 'The Terminal,' a true story" The Christian Science Monitor. (June 18) Retrieved Apr. 12, 2005 from http://www.csmonitor.com/2004/0621/p11s02-almo.html

Global Policy Forum. (2000). "Gypsies Want Global "Nation" to Fight Exclusion". In Agence

France Presse. July 25, 2000. Retrieved Apr. 12, 2005 from http://www.globalpolicy.org/nations/gypsy.htm

Gorlick, B. (2000). "Human rights and refugees: enhancing protection through international human rights law". New issues in refugee research working paper No. 30 Stockholm, Sweden: UNHCR.

Hajjar, L. (2005). "From Nuremberg to Guantánamo: International Law and American Power 
Politics", Middle East Report Retrieved Mar. 23, 2005 from

http://www.merip.org/mer/mer229/229_hajjar.html

Ilich, F. (2004). Mario Benedetti, el escritor Latinoamericano y la revolucion posible.

Retrieved Mar. 23, 2005 from Narrativemedia.org

http://www.zemos98.org/producciones/narrativa/weblog/?p=35

Indymedia Report (27 March 2005). Thai government silencing refugee voices. Indymedia.

Retrieved on March 28, 2005 from

http://www.indymedia.org/en/2005/03/113955.shtml

Kearns, A. (1995) Active citizenship and local governance: political and geographical dimensions. Political Geography 14, 155-76

Laguerre, M. (1998) Diasporic citizenship: Haitian Americans in transnational America. St. Martin's Press, New York.

Mahler, S. (2000) Constructing international relations: the role of transnational migrants and other non-state actors. Identities 7, 197-233.

Mitchell, K. (1998) Reworking democracy: contemporary immigration and community politics in Vancouver's Chinatown. Political Geography 17, 729-50

Mazrui, Ali A. (2004). Pax Islamica and Seven Pillars of Wisdom presented at CSID Fifth Annual Conference: "Defining and Establishing Justice in Muslim Societies" Washington, D.C. May 28- 29,2004. Retrieved April 17, 2005 from http://www.islam-democracy.org/documents/pdf/5th_Annual_ConferenceMazrui_address.pdf.

Neuffer, E. (1997). “A Man without a country French airport is 10-year home." Boston Globe (December 25). (reprinted) Retrieved Apr. 12, 2005 from http://www.geektimes.com/michael/culture/reality/merhan-nasseri/stranded.html

O'Connell, J. (1996). Travelers, Gypsies, Roma and Citizenship in the European Union. Retrieved Apr. 12, 2005 from www.paveepoint.ie/pav_eurounion.html

Ong, A. (1999) Flexible citizenship: The cultural logics of transnationality. Duke University Press, Durham.

Pal, L. (2001). Beyond Policy Analysis: Public Issue Management in Turbulent Times (2nd Ed.) Toronto: ITP Nelson.

Parekh, S. (2004). "A meaningful place in the world: Hannah Arendt on the nature of human rights". Journal of Human Rights. Taylor and Francis Ltd 3(1), pp. 41-53. Retrieved on March 26, 2005 from http://www.tandf.co.uk/journals.

Pillow, W. (1997). Decentering silences/troubling irony: Teen pregnancy's challenge to policy

analysis. In C. Marshall (Ed.), Feminist critical policy analysis: A perspective from primary and secondary schooling (pp. 134-152). London: Falmer Press.

Purcell, M. (2003). "Citizenship and the right to the global city: re-imagining the capitalist world order". International journal of urban and regional research. 27:3 pp. 564-90

Roberts, B. Frank, R. and Lozano-Ascencio, F. (1999) Transnational migrant communities and Mexican migration ot the US. Ethnic and Racial Studies 22, 238-240

Rhodes, R.A.W. (1996). “The new governance: governing without government" in Political Studies. Oxford. Blackwell Publishers. XLIV pp. 652-667.

Rosengaard, C. (1996). "The past is a lost country: Family narratives among ethnic Russians in Lativa". Anthropology of East Europe Review. 14:1 Spring. Retrieved April 17, 2005 from http://condor.depaul.edu/ rrotenbe/aeer/aeer14_1/rosengaa.html 
Rouse, R. (1995) Questions of identity: personhood and collectivity in transnational migration to the United States. Critique of Anthropology 15, 351-80

Sandel, M. (1996) Democracy's discontent: America in search of a public. Harvard University Press, Cambridge, MA.

Scheurich, J. J. (1994). "Policy archaeology: a new policy studies methodology" in Journal of Educational Policy Taylor and Francis Ltd. pp. 297-316

Schiller, N. Basch, L. and Blanc, C. (1995) From immigrant to transmigrant: theorizing transnational migration. Anthropological Quarterly 68, 48-64.

Skinner, K. (2005). "An Anthropological Assessment of Globalization Defined as Deterritorialization" presented at The Third International Conference on New Directions in the Humanities. Homerton College, University of Cambridge, UK, (2-5 August), Retrieved on April 12, 2005 from http://h05.cgpublisher.com/proposals/231/index_html

Soloman, A. (2004). Soldiers Choose Canada. Village Voice (Features: March 30, 2004) Retrieved April 6, 2004 from http://www.villagevoice.com/2004-0330/news/soldiers-choose-canada/

Soysal, Y. (1999) Toward a postnational model of citizenship. In G. Shafir (ed), The citizenship debates, University of Minnesota Press, Minneapolis.

Staeheli, L. (1994) Restructuring citizenship in Pueblo, Colorado. Environment and Planning A 26, 849-871.

Staeheli, L. Kodras, J. and Flint, C. (eds.) (1997) State devolution in America: implications for a diverse society. Sage, Thousand Oaks.

Süssekind, F. (2002). (Barros, M. Trans.) Deterritorialization and Poetic Form Brazilian Contemporary Poetry and Urban Experience. Retrieved April 17, 2005 from http://arachne.rutgers.edu/vol2_1sussekind.htm.

Swyngedouw, E. (1996) Reconstructing citizenship, the re-scaling of the state and the new authoritarianism: Closing the Belgian mines. Urban Studies 33, 1499-1521.

Symonides, J. (1998). Message from the Director-General of UNESCO to the International Conference on "The Implementation of The Right to Self-determination as a Contribution to Conflict Prevention" Report of the international conference of experts held in Barcelona from 21 to 27 November 1998. Available at: http://www.unpo.org/news_detail.php?arg=01\&par=446

Trend, D. (1995) Radical democracy: identity, citizenship, and the state. Routledge, London.

Ward, K. (2000) A critique in search of a corpus: re-visiting governance and re-interpreting urban politics. Transactions of the Institute of British Geographers 25, 169-185.

Weil, S. (2002). Wills, A. (trans.) The need for roots: prelude to a declaration of duties toward mankind. London and New York. Routledge Classics.

Yaghmaian, B. (2003). A person of no concern. Le Monde diplomatique Retrieved Mar. 28, 2005 from http://www.rozanehmagazine.com/MayJune03/aafghan.html

Yuval-Davis, N. (1999) "The multi-layered citizen": citizenship at the age of "glocalization”. International Feminist Journal of Politics 1, 119-136. 